Resumen por el autor, E. P. Allis, Jr.

Sobre ciertos rasgos de los canales laterosensoriales de los Plagiostomos.

El trabajo más reciente sobre el desarrollo del sistema laterosensorial de los Plagiostomos parece establecer que las líneas sensoriales de estos peces se desarrollan todas en las capas más profundas, solamente en el ectodermo; que cada órgano sensorial se hunde interiormente con independencia, produciendo primero de este modo una serie de organos en forma de hoyito; que el hundimiento contínuo de estos órganos y la invaginación concomitante de la línea sensorial entre los órganos sucesivos y su constricción de la porción subyacente del ectodermo produce una serie de hoyitos en forma de frasco, relacionados mediante un cordón de tejido sensorial, que es morfológicamente tubular, pero aparece sólido a consecuencia de la presión de sus paredes; y que la expansión subsiguiente de los hoyitos en forma de frasco a lo largo de las líneas centrales de estos cordones y la coalescencia de los hoyitos adyacentes, produce los canales del adulto. Las líneas hiomandibular $\mathrm{y}$ ventral del cuerpo, $\mathrm{y}$ los nervios que las inervan, se desarrollan en conexión con las placodas epibranquiales, mientras que las otras líneas sensoriales y los nervios con ellas relacionadas se desarrollan en relación con las placodas dorsolaterales. La placoda dorsolateral que produce el ramo oftálmico superficial, bucal y ótico lateral y las líneas sensoriales con ellos relacionadas, se desarrolla en relación con células de la cresta neural, que adquieren después su connexión central con células pertenecientes al nervio facial, pero parece muy probable que esta asociación de células es de orígen secundario y que las células primeras pertenecen, morfológicamente, al nervio trigémino.

Translation by José F. Nonidez Cornell Medical College, New York 
AUTHOR'S ABSTRACT OF THIS PAPER ISSUED BY THE BIBLIOGRAPHIC SERVICE, OCTOBER 30

\title{
ON CERTAIN FEATURES OF THE LATERO-SENSORY CANALS OF THE PLAGIOSTOMI
}

\author{
EDWARD PHELPS ALLIS, JR.
}

Menton, France

The manner in which the latero-sensory canals of the Plagiostomi are developed seems still uncertain. They were formerly considered, on Balfour's authority, to be developed by dehiscence in a solid cord of tissue which had been constricted from the deeper layers of the ectoderm, but remained attached to it at intervals by much smaller, and also solid cords, the latter cords later becoming, also by dehiscence, the tubules leading to the outer surface. In 1901 I examined these canals in four series of sections of embryos of Mustelus, 36-mm., 55-mm., and 122$\mathrm{mm}$. in length, and after stating that I could not make out, from the conditions in these three embryos, the manner in which the canals were developed, I added (l. c., p. 91):

My own observations, limited to the four series of sections that I possess, tend to confirm Balfour's statement that the lateral canals are formed by an involution of the deeper layer only of the ectoderm. The covered gutter, rather than canal, that is thus first formed then becomes, by a pressing together of its walls, a sharp and apparently solid ridge projecting inward from the inner surface of the ectoderm. This is the condition found nearly everywhere in my $36 \mathrm{~mm}$. embryo. Where the cord is deepest it receives a branch from the underlying and related lateral nerve, but there is as yet no perceptible indication in my sections of a definite sensory organ related to this nerve. Between each two consecutive points where these nerves thus join the cord, the cord becomes less deep, and in the regions where it is the flattest, there is a small pit-like depression on the outer surface. This depression looks in certain sections like a shallow groove, while in others it has vertical sides, and seems to cut clean through the outer layer of ectoderm down to that deeper layer that is alone directly related to the canal itself. This depression, or pit, quite certainly represents a future pore, the pore thus apparently appearing while the cord that represents the canal is still everywhere attached to the ectoderm. 
In my $55 \mathrm{~mm}$. specimen the lateral canals were mostly found as cords of tissue lying in the mesoderm, beneath the ectoderm, and connected with the latter at intervals by smaller cords, which represent the tubules of the adult. In the large main cords there was a small, central lumen, either formed or in process of. formation, and this lumen was always most fully developed opposite the points from which the cords representing the future tubules arose. In certain places it extended outward a short distance in these latter cords, but in no place did it reach the outer surface of the head. On this outer surface of the head there was, however, almost invariably, opposite the outer ends of the cords that represent the primary tubes, a slight slit-like depression, the appearance being that of a pre-existing opening that had been closed by the pressing together of its walls.

Even at this age, $55 \mathrm{~mm}$., there was no perceptible indication, in my sections, of the sensory organs in the main canals.

In 1905, Klinkhardt examined these canals in embryos of Spinax niger, and there found them developed by a sinking in of the entire ectoderm along the latero-sensory lines and the subsequent arching over and coalescence of the edges of the grooves so formed, and he says ('05, p. 461) that, in this manner of development of these canals, he confirms the earlier observations of van Wijhe and Mitrophanow. Guthke later ('06) found the canals developed in this same manner in Torpedo ocellata, and still later Johnson ('17) so finds them developed in both Mustelus canis and Squalus acanthias. Johnson, furthermore, describes somewhat in detail the manner in which the canals are formed, which neither Klinkhardt nor Guthke does. According to him, the groove first formed is continuous the full length of each sensory line, and it is shown, in the figures given, as a narrow groove the width of which is only that of the space occupied by the outer ends of the sensory cells of the related organs, transverse sections through it resembling those through the depressions which I described in Mustelus as representing the future pores and also those through pit-organs of the Teleostomi. These so-called grooves of these fishes thus do not at all resemble those formed in connection with the development of the latero-sensory canals in the Teleostomi, the invagination there including the entire latero-sensory organ together with a certain amount of adjacent ectoderm. Furthermore, that 
coalescence of the lips of these grooves of the Plagiostomi that is said to give rise to the canals must take place between successive organs of a line, instead of, as in the Teleostomi, directly above them, for the tubules of a line almost invariably arise, in the former fishes, from the canal directly opposite an organ, instead of between successive organs.

The next work on this subject that I know of is by Gudrun Ruud ('20), who had at her disposal a large and very complete series of embryos of Spinax niger, and the development of the canals in this fish, as described by her, is totally different from that just above referred to, and fully in accord with my own observations on Mustelus. According to Ruud, the organs of the latero-sensory lines develop in the deeper layer, only, of the ectoderm, the outer, epithelial layer ('Plattenepithel,' Ruud) not being involved in the process, but later breaking down above the organ. Each organ then sinks separately and independently beneath the surface, thus first giving rise to a series of pits which closely resemble those of the pit-organs of the Ganoidei and Teleostei. The sinking process, however, here continues, and as the pits become deeper their bottoms become enlarged and their necks constricted, the simple surface pits first formed thus being converted into flask-shaped depressions with an organ at the bottom of each flask. Those parts of each sensory line that lie between successive ones of these flask-shaped pits then become constricted from the overlying layers of the ectoderm, a solid cord thus being formed between each pair of flasks. The bottoms of the flask-shaped pits then become still further enlarged, the enlargements taking place in the direction of the lines of the connecting cords, and adjacent pits soon touch and then fuse with each other, and so give rise to a continuous canal.

This method of development of the canals in Spinax niger is so strikingly different from that described by Johnson in the fishes examined by him that no comparison seems possible, and yet the figures given by the two authors of transverse sections through the sensory lines are strikingly similar. The subject evidently needs control, but it is to be noted that the develop- 
ment, as described by Ruud, fully explains, and is fully in accord with, the conditions that I found in my $36-\mathrm{mm}$. and 55-mm. embryos of Mustelus, the hollows in the necks of the flaskshaped pits in my $55-\mathrm{mm}$. specimen having been rendered unrecognizable by the pressing together of their walls, but the outer openings of the pits persisting in the small pit-like depressions on the outer surface of the head. My impression accordingly is that Ruud's description of the development of these canals is correct, and in favor of this conclusion is the fact that the invagination of each organ of a line, as described by her, is similar to the invagination of the auditory vesicle, while the formation of a canal from the sharp and narrow groove described by Johnson would have no parallel that I know of in the development of any part of the latero-sensory system.

In her further description of the latero-sensory system of Spinax, Ruud says that the main horizontal latero-sensory canal of the adult is represented, in a 23-mm. embryo, by a series of longitudinally disposed thickenings of the ectoderm, four short and one long, which lie one above each of the five clefts that have broken through at this stage, the anterior thickening lying above the spiracular cleft and being preauditory in position, and the other four lying above the branchial clefts and being postauditory in position.

The anterior one of the four postauditory thickenings begins above the first branchial cleft and extends posteriorly nearly to the second cleft, thus, at this stage, lying dorsal to the first branchial arch, rather than to the first branchial cleft. This thickening is innervated by what Ruud calls the lateral branch of the nervus glossopharyngeus, and it gives rise to the glossopharyngeus section of the main horizontal canal of the adult. Immediately dorsal to its anterior end, but, at this age, disconnected with it, a short ectodermal thickening runs dorsally and gives rise to two pit-organs (Spaltpapillen) which lie directly anterior to the external opening of the ductus endolymphaticus. This dorsoventral thickening is innervated by a branch of the so-called lateral branch of the glossopharyngeus, and Ruud calls this branch, alone, the supratemporal branch of the glossopharyn- 
geus. The next posterior thickening lies above the second branchial cleft and has related to its anterior end a dorsally directed thickening which gives rise to the supratemporal crosscommissural canal of the adult, these two thickenings being innervated, respectively, by what Ruud calls the lateral branch of the first vagus ganglion and the supratemporal branch of that branch. The next posterior horizontal thickening lies above the third branchial cleft, has related to its anterior end a dorso-posteriorly directed thickening which gives rise to the dorsal line of pit-organs of the adult, and posteriorly is continuous with the thickening related to the fourth branchial cleft, the two thickenings being separated by a constricted portion of a continuous line. The posterior thickening is prolonged posteriorly considerably beyond the branchial region and represents the lateral line of the adult. The thickenings above these last two clefts are in contact with that part of the vagus ganglion that lies posterior to the first vagus ganglion, and are connected with it by nerve strands. In the oldest stage examined by Ruud the supratemporal commissure has shifted forward and lies anterior to that section of the main horizontal canal that is innervated by the glossopharyngeus, this change of position being ascribed to the increased cranial flexure.

The one preauditory horizontal thickening lies above the spiracular cleft and is said to give rise to that part of themain horizontal canal that is innervated by the ramus oticus. Ruud considers this oticus thickening to represent the anterior end of the horizontal portion of the canal system, and she says ('20, p. 498) that the supraorbital and infraorbital thickenings, which begin slightly anterior to the oticus thickening and have their accustomed relations to the eyeball, correspond, in their relations to the oticus thickening, to the dorsally directed lines related to the postauditory thickenings. While this probably applies to the supraorbital line, it would seem as if it could not apply to the infraorbital one. The interval between the oticus and glossopharyngeus thickenings is much greater than those between the more posterior thickenings, and while this may be in part due to the cranial flexure, it is probably largely due to the 
utilization of an intervening part of the line of horizontal thickenings to form the ear. This will be later again referred to.

These several sensory thickenings are said to each develop in relation to a dorso-lateral placode (Lateralverbindung, Ruud), and the nerves that innervate them are said to each develop in the deeper layer of the related thickening and to later split off from it and sink into the mesenchyme. There are, however, two other ectodermal lines, the hyomandibular and ventral body lines, which are said to be developed wholly independent of the dorso-lateral placodes.

The thickening that represents the hyomandibular line is said to lie, in the $23-\mathrm{mm}$. embryo, anterior to, and nearly parallel to, the first branchial cleft and to extend toward the ventral surface of the embryo, and it is shown, in the figures given, widely separated from the horizontal line of thickenings. A dorso-ventrally directed line of pit-organs is said to develop from it, and from near its dorsal end a short branch line is said to be directed forward and to give rise to the so-called hyomandibular canal of the adult. Both these lines are said to be innervated by the ramus hyomandibularis facialis, which is said to arise from the epibranchial branch of the facialis ganglion and to run downward in the hyal arch in close contact with the hyomandibular ectodermal thickening. No separate ganglion is described in relation to this nerve, and emphasis is placed on the fact that it is a postbranchial branch of the epibranchial branch of the primitive acustico-facialis ganglion, and that neither it nor the line it innervates is in any way derived from a dorso-lateral ectodermal thickening. The ventral body line is not evident as an ectodermal thickening in the $23-\mathrm{mm}$. embryo of Spinax, but is in a $29-\mathrm{mm}$. embryo. It lies posteroventral to the branchial clefts, is said to be innervated by a posttrematic branch of one of the posterior vagus nerves, and of it Ruud says (1. c., p. 500): "Hier, wo keine Spaltung der Lateralverbindung stattfindet, entwickeln sich wieder postbranchiale Sinnesorgane."

Neither the hyomandibular latero-sensory organs of this fish nor the nerve that innervates them thus, according to Ruud's 
observations, receives any contribution of cellular material from the dorso-lateral placodes, and although this is not in accord with what has been a generally accepted view (Johnston, '06, p. 59), it would seem to be confirmed by the conditions described by Klinkhardt in embryos of this same fish (Spinax niger) and by Guthke in embryos of Torpedo ocellata. Klinkhardt says ('05, pp. 450 and 473) that, in Spinax niger, a process of the acustico-facialis ganglion is directed toward the hyal arch and comes into contact with thickened ectoderm at the dorsal end of the spiracular cleft, there forming a placode. This placode is the only one he could definitely identify in relation to the facialis ganglion, and he is at first uncertain as to whether it is a dorso-lateral or an epibranchial one, but when he later finds, in Torpedo, a typical epibranchial placode in corresponding place, with a dorso-lateral placode dorsal to it, he concludes that the single placode in Spinax must be an epibranchial one. The ramus hyomandibularis (called by Klinkhardt the ramus hyoideus) is said to arise in relation to this placode and to run downward in the hyal arch, there lying at first free in the mesenchyme. Farther ventrally it acquires contact with the ectoderm, and, when this contact is later given up, remains there connected with the ectoderm by a branch which is said to represent the 'first beginning' of the ramus mandibularis externus. The latter nerve is thus considered by this author to be of epibranchial origin, and that part of it that lies between its ganglion and the point where it first acquires contact with the ectoderm is not split off from the deeper layer of the laterosensory ectodermal thickening to which it there becomes related. Furthermore, no ganglion is formed in relation to it at the point where it acquires contact with this ectodermal thickening, the ganglion cells to which it is related being of neural-crest or epibranchial origin. In Torpedo ocellata this nerve is developed, according to Guthke ('06), in practically the same manner as that above set forth for Spinax niger.

The ramus mandibularis externus facialis of the Plagiostomi is thus apparently not developed in relation to a dorso-lateral placode, and yet it is certainly a latero-sensory nerve, for in 
older embryos of these fishes it has a ganglion of its own, which lies in the truncus hyomandibularis in part distal to the communis ganglion of that nerve, and its fibers join those roots of the nervus facialis that have their central origins in the lateralline lobe and the acusticum (Norris and Hughes, '20). In topographical position it is a ventral nerve, and it is certainly not the serial homologue of the supratemporal (dorsal) branches of the nervi glossopharyngeus and vagus. The question then is, is the nervus acusticus, or the combined rami oticus, ophthalmicus superficialis and buccalis lateralis, the homologue, in the hyal arch, of the dorsal branches of the more posterior nerves? and the descriptions of the early stages of development of these nerves would seem to indicate that it is the nervus acusticus.

In an 8-mm. embryo of Torpedo ocellata, Guthke finds ('06, pp. 35-38) the acustico-facialis ganglion, apparently composed entirely of neural-crest cells, in contact with the ectoderm at three points. One of these contacts lies at the dorso-posterior border of the spiracular cleft and there forms a typical epibranchial placode, and from this placode three nerves arise, a ramus posttrematicus (hyomandibularis facialis), a ramus pretrematicus and a ramus pharyngeus. A second contact lies dorsoanterior to this one, near the anterior edge of the ganglion and in the horizontal line of the dorso-lateral placodes. From this contact the ramus ophthalmicus superficialis lateralis arises, and Guthke says that this nerve is strictly comparable to the dorsal branches of the glossopharyngeus and vagus, and hence is the ramus dorsalis of the acustico-facialis ganglion, the ramus buccalis, which is said to arise from the root of the ramus ophthalmicus and to run downward in the mandibular arch, being the related ramus ventralis. The third contact is with the auditory vesicle, and is considered by Guthke to be a dorso-lateral contact. From it the nervus acusticus arises, and this nerve is considered by him to be a ramus dorsalis, the ramus hyomandibularis being the related ramus ventralis. The entire acusticofacialis ganglion is accordingly said by Guthke to show a definite division into two parts, but he nevertheless assigns both parts to the nervus facialis. The trigeminus ganglion is said to have an 
epibranchial placode developed in relation to it, and slightly dorsal to this placode, but not at all in the level of the dorsolateral ones, there is said to be, in the earliest stages examined, 'eine schwache Lateral-verbindung' (l. c.. p. 34). This contact disappears in the following stages, and Guthke was unable to further follow it.

Klinkhardt found, in Spinax niger, no placode related to the trigeminus ganglion, and none related to the acustico-facialis ganglion in the two younger stages described by him. In the oldest stage described, the latter ganglion has, however, acquired two contacts with the external ectoderm and one with the auditory vesicle, the two contacts with the external ectoderm being one dorso-lateral and the other epibranchial. The ganglion is, at this age, markedly separated into two parts, the dorsolateral contact being related to the anterior division, and the auditory and epibranchial ones to the posterior division. The anterior division of the ganglion has grown forward superficial to the trigeminus ganglion, forcing the latter away from the ectoderm and there acquiring contact with it, and the dorsolateral placode that results from this contact lies superficial to the trigeminus ganglion and directly dorsal to the mandibular arch, in exactly the position that it would have if it were related to this latter arch and the nervus trigeminus, and not to the nervus facialis.

The conditions described in these embryos thus warrant the assumption that the nervi oticus, buccalis, and ophthalmicus lateralis are branches of the trigeminus, and this is in accord with their topographical relations, in the adults of the Teleostomi, to skeletal elements, which is, as I have shown in several of my works, strictly that of trigeminus nerves. The nervus acusticus would then be the true dorsal branch of the facialis, and the facialis portion of the horizontal latero-sensory line and the related dorsally directed supratemporal line would both have been invaginated to form the auditory vesicle, this perhaps accounting for the two divisions of the nervus acusticus. There must then have been, in this region, a segregation and subsequent condensation of neural-crest cells, certain cells that 
belonged primarily to the nervus trigeminus becoming separated from that nerve and joining the nervus facialis, this possibly accounting for the break in the neural crest between these two nerves. This association of these trigeminus cells with those of the facialis has, however, persisted only for those proximal cells that give origin to the root of the future nerve, the more distal cells migrating forward, in an apparent effort to rejoin the parent body, and acquiring contact with the lateral ectoderm in the trigeminus region, at the point where they normally should. There a dorso-lateral placode and ganglion are formed, both of which seem certainly to belong, morphologically, to the nervus trigeminus, notwithstanding that the ganglion is connected with the medulla by root fibers that are associated with those of the facialis. This placode is shown by both Klinkhardt and Guthke lying anterior to the line prolonged of the spiracular cleft, but the primordium of the oticus portion of the horizontal latero-sensory line is shown by Ruud lying in that line prolonged. This position of this primordium is, however, no positive evidence that that was the primary relation, to the spiracular cleft, of the ectodermal cells from which it is derived, for the dorsal end of that cleft has shifted markedly forward and there is nothing to show that the oticus ectodermal thickening has undergone a corresponding forward movement.

In the Ganoidei and Teleostei the latero-sensory lines and related nerves are said to be developed in a somewhat different manner from that above described in the Plagiostomi. Here, according to both Wilson ('91) and Landacre ('10, '12), the dorso-lateral placodes first appear as a single continuous ectodermal thickening which later separates into three parts, the middle one giving origin to the auditory vesicle and the other two to what Landacre calls the preauditory and postauditory placodes. Wilson says that, in Serranus, the two latter placodes give origin, respectively, to the preauditory and postauditory latero-sensory lines and the related ganglia and nerves. Landacre, on the contrary, says ('10, p. 386) that, in Ameiurus, both the preauditory and postauditory lateral-line organs are entirely distinct in origin from the placodes; and of the preauditory 
placode he says ('10, p. 339): "The later history of this placode shows that for a time it becomes more definite in appearance, simulating closely a lateral- line organ and, on a small scale, the changes in the auditory vesicle, and then later disappears entirely, the greater portion of it being converted into mesectoderm. It does not give rise to either ganglia or lateral line organs." The lateral-line organs are said ('10, p. 357) to be "definite differentiations of the epidermis, just as are the taste buds, and the nerves which supply them grow from specific ganglia just as in the case of the gustatory nerves." Regarding the conditions in Lepidosteus, Landacre says ('12, p. 31): "The presence of definite sensory lines resembling those of the sea bass (Wilson, '91) shows that the lateral line system, at least in its earliest stages, resembles Serranus much more closely than Ameiurus, but whether these sensory lines are continuous with the anterior end of the auditory thickening (preauditory placode of Ameiurus, Landacre, '10) or not must be taken up separately." And he later concludes, by comparison with the postauditory placode and latero-sensory lines, that these lines arise wholly independent of the placode, as they were said to do in Ameiurus.

It would thus seem as if the latero-sensory organs in these two large groups of fishes, the Plagiostomi and Teleostomi, differed radically not only in the manner in which they become enclosed in their canals, but also in their relations to the dorsolateral placodes and in the manner of development of the nerves that innervate them, these nerves splitting off from the deeper layer of the latero-sensory ectodermal thickening in the Plagiostomi (excepting in the case of the hyomandibular and ventral body lines), but in the Teleostomi growing outward in the mesenchyme until they find their appropriate organs. There is even the suggestion that the organs that develop in relation to the preauditory and postauditory placodes of the Teleostomi and later disappear may be the homologues of the latero-sensory organs of the Plagiostomi, the definitive organs of the Teleostomi not then having their exact homologues in the former fishes. But, however this may be, the important point in the present 
discussion is Johnston's statement ('06, pp. 59-60) that the dorso-lateral placodes evidently, in the early history of vertebrates, occupied three segments of the body, and that: "It is probable that at first the portions of the system in the three segments were independent of one another." If Johnston is correct in this assumption, made some years ago, it seems certain that each of these three portions of the latero-sensory system was innervated, in these early vertebrates, by the nerve of the segment to which it belonged, and it is equally certain that the middle one of the three portions, from which the auditory vesicle is developed, must have belonged to a segment that lay between those to which the mandibular and first branchial arches of recent fishes are respectively related, and if there be but one segment in this interval it must be the one to which the hyal arch is related. The preauditory placode would then belong to the mandibular arch, and the ganglion and nerves related to it would belong to the nervus trigeminus.

There thus seems good and sufficient reason to consider the rami oticus, buccalis, and ophthalmicus lateralis as branches of the nervus trigeminus, and they should then be so designated. If they are still to be considered as branches of the facialis, and to be so designated, consistency would require some corresponding name for the lateralis fibers that form part of the supratemporal branch of the nervus glossopharyngeus, for, in Ameiurus, these fibers and their ganglion are said by Landacre ('10, p. 385) to arise "chiefly, if not entirely, by proliferation of cells from the posterior end of the auditory vesicle," the auditory ganglion and nerve arising from other parts of the same vesicle. Furthermore, in this same fish, communis fibers derived from the geniculate ganglion are said by Landacre ('07) to run out in each of the three main branches of the nervus trigeminusthe rami maxillaris, mandibularis, and ophthalmicus superficialis -and yet no one has ever suggested that these fibers should be given names to indicate that they were considered to be branches of the nervus facialis. Great confusion would inevitably arise if any such nomenclature were to be adopted, and it presupposes that the present central origin of nerve fibers, 
and not their peripheral relations to skeletal and other elements, determines the nerve to which they primarily belonged. If the oticus, buccalis, and ophthalmicus lateralis belong to the nervus trigeminus, they evidently correspond, respectively, to those branches of the glossopharynegus and vagus that Ruud describes as their lateral and supratemporal branches, the oticus-buccalis being related to an anterior prolongation of the main horizontal latero-sensory line, and the ophthalmicus superficialis to a related dorsally directed line. That the buccalis can be either a dorsal branch (Ruud) or a ventral one (Guthke) is wholly inconsistent with its course through the orbit, where it passes ventral to the nervus opticus and closely accompanies the ramus maxillaris trigemini, which is certainly not a posttrematic nerve.

One further point in Ruud's work may now be mentioned. That author, after describing the distribution and development if the ampullae in Spinax, refers ('20, p. 539) to my conclusion, on my work on Mustelus, that: "The terminal buds of Ganoids, the nerve sacs of Acipenser, and the ampullae of selachians are in all probability homologous structures." She then says that "Johnston veröffentlicht in demselben Jahre eine diese Theorie stark verdammende Kritik," but, after briefly stating three features in the development of the terminal buds in Amia, as described by me, says: "Diese drei Eigentümlichkeiten sind beiden Arten von Organen gemeinsam, und vergleicht man ein Spinax-Stadium von $28-29 \mathrm{~mm}$. mit einem Amia-Stadium von Allis, so muss man notgedrungen auf den Gedanken kommen, dass das, was hier bei Spinax Ampullenanlagen darstellt, dem entsprechen muss, was bei Amia die Anlage der 'terminal buds' ist. Natürlich sind diese rein äusserlichen Gleichheitspunkte an und für sich kein Beweis; aber meiner Meinung nach muss man das Recht besitzen, ihnen so viel Gewicht beizulegen, dass man trotz Johnston's Kritik diesen Dingen nach wie vor seine Aufmerksamkeit zuwendet und Allis' Anschauung nicht gleich als ganz unannehmbar verwirft."

Stendell ('16) finds, in Mormyrus, organs which he refers to as 'Schnauzenorgane,' which are said to represent a combina- 
tion of a sensory apparatus with a glandular one. The sensory cells are said to correspond, in form, almost exactly to those of terminal buds, but to be innervated by branches of the lateralis nerves. Stendell accordingly considers these organs to represent a special type which is intermediate between terminal buds (Geschmacksknospen) and neuromasts (Endhügeln).

Palais de Carnolès, Menton, March 27, 1922.

\section{LITERATURE CITED}

ALLIS, E. P. 1901 Lateral sensory canals, eye-muscles and the peripheral distribution of certain of the cranial nerves of Mustelus laevis. Quart. Journ. Micros. Soc., vol. 45, pp. 87-236.

Brohmer, P. 1909 Der Kopf eines Embryos von Chlamydoselachus und die Segmentierung des Selachierkopfes. Jena. Zeits. f. Naturwiss., Bd. 44, S. 647-698.

Gutruke, E. 1906 Embryologische Studien über die Ganglien und Nerven des Kopfes von Torpedo ocellata. Jena. Zeits. f. Naturwiss., Bd. 42, S. 1-57.

JoHNson, S. E. 1917 Structure and development of the sense organs of the lateral canal system of selachians (Mustelus canis and Squalus acanthias), Jour. Comp. Neur., vol. 28, no. 1.

Johnston, J. B. 1906 The nervous system of vertebrates, Philadelphia.

KLINKHARDt, W. 1905 Beitrag zur Entwicklungsgeschichte der Kopfganglien und Sinneslinien der Selachier. Jena. Zeits. f. Naturwiss., Bd. 40, S. 424-486.

LANDACRE, F. L. 1907 The place of origin and method of distribution of tastebuds in Ameiurus melas. Jour. Comp. Neur., vol. 17, pp. 1-66. 1910 The origin of the cranial ganglia in Ameiurus. Jour. Comp. Neur., vol. 20, pp. 309-411.

1912 The epibranchial placodes of Lepidosteus osseus and their relation to the cerebral ganglia. Jour. Comp. Neur., vol. 22, pp. 1-70.

Norris, H. W., AND HuGHes, S. P. 1920 The cranial, occipital and anterior spinal nerves of the dogfish, Squalus acanthias. Jour. Comp. Neur., vol. 31, pp. 293-402.

RUUn, GUdRun 1920 Ueber Hautsinnesorgane bei Spinax niger Bon. Zool. Jahrb. Abt. f. Anat., Bd. 41, S. 459-546.

Stendell, W. 1916 Die Schnauzenorgane der Mormyriden. Zeit. Wiss. Zool., Bd. 115, S. 659-669.

Wilson, H. V. 1891 The embryology of the sea bass. Washington. 